\title{
REVITALISASI LITERASI KESEHATAN DAN KETAHANAN KESEHATAN MASYARAKAT DI KALANGAN MILINEAL
}

\author{
Syarifah Ema Rahmaniah ${ }^{1}$, Syarmiati $^{2}$, Rizqi Ratna Paramitha ${ }^{3}$ \\ ${ }^{1}$ MAFINDO Pontianak, Fakultas Ilmu Sosial dan Politik UNTAN Pontianak \\ ${ }^{2}$ Fakultas Ilmu Sosial dan Politik UNTAN Pontianak \\ ${ }^{3}$ Fakultas Ilmu Sosial dan Politik UNTAN Pontianak
}

Email korespondensi : syf.ema@fisipuntan.ac.id

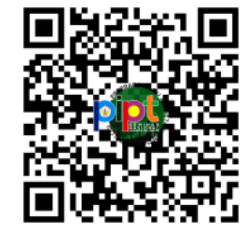

$10.26418 /$ pipt.2021.36

\begin{abstract}
Tingginya penyebaran COVID-19 bagi kelompok masyarakat yang rentan terhadap bahaya COVID-19 salah satunya disebabkan oleh rendahnya literasi kesehatan. Penelitian ini bertujuan untuk mengidentifikasi tingkat literasi kesehatan bencana non alam COVID-19 di kalangan mahasiswa Pembangunan Sosial dan Sosiolog FISIP Universitas Tanjungpura Pontianak dengan cara mengenalkan materi edukasi kawal COVID-19 oleh Masyarakat anti Fitnah Indonesia (MAFINDO). Pengukuran dilakukan melalui survei kuesioner online yang melibatkan 102 responden yang ditentukan secara purposive sampling. Data dianalisis menggunakan statistik korelasi Pearson. Hasil penelitian menunjukkan bahwa tingkat literasi edukasi kesehatan untuk pencegahan penyebaran COVID-19 mencapai tingkat yang memadai dengan pencapaian terbaik dalam dimensi keterampilan melakukan cek fakta, dan dimensi pengetahuan tata kelola hidup sehat. Ditemukan bahwa mahasiswa semester atas yaitu semester 6 dan 8 memiliki tingkat literasi kesehatan lebih baik. Tidak ada hubungan yang signifikan antara literasi kesehatan mahasiswa dengan perbedaan gender dan program studi. Kami merekomendasikan peningkatan literasi edukasi kesehatan melalui program literasi digital yang fokus pada pendidikan anti hoax dan pelatihan cek fakta di tingkat perguruan tinggi.
\end{abstract}

Kata kunci: COVID-19, literasi kesehatan, MAFINDO, Kawal COVID-19.

\section{PENDAHULUAN}

Fenomena sosial kesehatan yang terjadi sejak Desember 2019 adalah wabah penyakit varian baru yang dikenal sebagai Corona Virus Diseases atau COVID-19. Demikian massifnya wabah ini memaksa organisasi kesehatan dunia WHO menyatakan wabah penyakit ini sebagai pandemi, yang artinya berdampak meluas hampir keseluruhan negara di dunia, tak terkecuali Indonesia. Permasalahan yang muncul dalam upaya pencegahan wabah itu meluas dilihat dari rendahnya partisipasi masyarakat dalam mendukung kebijakan Social Distancing maupun Pembatasan Sosial Berskala Besar (PSBB) atau yang dikenal dengan sistem karantina (Gostic et al., 2020; Hellewell et al., 2020; Wells et al., 2020). Rendahnya partisipasi terlihat masih banyak masyarakat yang beraktivitas di luar rumah, tanpa memperhatikan protokol kesehatan COVID-19 seperti berkumpul dalam jumlah besar tanpa menjaga jarak aman dan tidak menggunakan masker, serta tidak juga sering mencuci tangan dengan menggunakan sabun atau penggunaan sanitizer (Djalante et al 2020).

Menurut Zarcadoolas et al (2006) literasi kesehatan adalah, the wide range of skills and competencies that people develop to seek out, comprehend, evaluate, and use health information and concepts to make informed choices, reduce health risks, and increase quality of life. Pernyataan serupa disampaikan oleh Berry et al (2007) bahwa literasi kesehatan merupakan kemampuan kognisi seseorang yang membuat seseorang mampu secara fasih memaknai kata-kata, membaca dengan cepat dan tepat , menangkap kata kunci dalam informasi visual, dan dapat memilih dan memilih halhal yang penting dari sebuah informasi. 
Berdasarkan beberapa penelitian tentang literasi kesehatan di beberapa negara salah satunya tingkat literasi kesehatan di Turki hanya terdapat $71,9 \%$ responden yang memiliki tingkat literasi kesehatan yang rendah (Ozdemir et al 2010). Adapun di Indonesia belum banyak kajian terkait tingkat literasi kesehatan masyarakat.

Untuk melakukan transformasi pengetahuan yang diperlukan adalah tidak hanya model edukasi formal namun juga edukasi non formal sebagaimana yang ditekankan Devlin et al., (2017) dan Mok (2011) untuk meningkatkan dan mendukung program pembangunan diperlukan pendidikan nonformal yang menjadi lembaga pendidikan yang berkoordinasi dengan lembaga lainnya seperti lembaga lingkungan, gender, media, sosial, budaya dan lembaga olahraga (Norqvist et al., 2016). Berdasarkan riset Rahmaniah et.al (2020) salah satu komunitas yang fokus pada gerakan literasi dan edukasi anti hoax adalah Masyarakat Anti Fitnah Indonesia (MAFINDO) yang menggunakan pendekatan daring dan luring. Semasa pandemic COVID-19 terjadi di Indonesia model edukasi berbasis daring menjadi sangat efektif untuk dipraktekkan, meskipun model edukasi ini belum bisa terjangkau sampai ke pelosok pedalaman karena keterbatasan jaringan internet dan fasilitas listrik. Namun untuk wilayah perkotaan atau perdesaan yang sudah memiliki akses listrik dan internet, model edukasi untuk melakukan upaya pencegahan dan tata kelola hidup sehat dan aman semasa pandemic COVID-19 social media banyak digunakan oleh masyarakat untuk bertukar informasi sesama keluarga, teman dan tetangga (Jang \& Baek, 2019). Penggunaan Whatapps grup, Facebook, Serial webinar adalah bagian dari media sosial dan aplikasi meeting secara daring yang tidak hanya digunakan sebagai sarana komunikasi dan penyebaran informasi tetapi juga media literasi dan edukasi yang efektif untuk menyampaikan informasi terkait pandemi (Parmer et al., 2016).

Berdasarkan fenomena tersebut, dalam konteks upaya pencegahan meluasnya wabah COVID-19 dibutuhkan kerjasama semua pihak dan mendorong partisipasi masyarakat luas. Masyarakat Anti Fitnah Indonesia (MAFINDO) Pontianak bekerjasama dengan tim Pengabdian Kepada Masyrakat Fakultas Ilmu Sosial dan Politik Universitas Tanjungpura Pontianak melakukan upaya pencegahan meluasnya wabah COVID-19 tersebut. Adapun kegiatan yang dilakukan adalah sosialisasi edukasi kawal COVID-19 di kalangan mahasiswa ilmu Sosiologi dan Pembangunan Sosial yang tersebar di 14 kabupaten kota di Provinsi Kalimantan Barat. Oleh karena itu penulis merasa penting untuk mengidentifikasi tingkat literasi kesehatan masyarakat terutama sekali kalangan anak muda dalam merespon wabah COVID-19 setelah mendapatkan edukasi kawal COVID-19.

\section{METODE PENELITIAN}

Penelitian ini dilakukan di Fakultas Ilmu Sosial dan Politik Universitas Tanjungpura Pontianak. Kami menerapkan metode survei untuk mengumpulkan informasi literasi kemanusiaan dengan kuesioner online. Populasi adalah mahasiswa Sosiologi dan Pembangunan Sosial dan pengambilan sampel ditentukan secara sengaja yaitu Purposive sampling para mahasiswa yang telah mendapatkan materi edukasi cara hidup sehat dan aman semasa pandemic yang telah disediakan oleh komunitas Masyarakat Anti Fitnah Indonesia (MAFINDO) di Pontianak Kalimantan Barat. Instrumen digunakan dalam bentuk formulir Google. Formulir online yang didistribusikan kepada 120 Mahasiswa FISIP dan terdapat 102 responden memberikan tanggapan sepenuhnya. Tujuan kegiatan ini adalah untuk mengidentifikasi persepsi mahasiswa terkait edukasi Kawal COVID-19. Kedua, untuk memaparkan kemanfaatan program edukasi kawal COVID-19.

\section{HASIL DAN PEMBAHASAN}




\section{Profil Responden}

Masyarakat anti fitnah Indonesia (MAFINDO) melihat masih banyak masyarakat yang belum mendapatkan akses informasi seputar COVID-19 padahal informasi tersebut harus diterima masyarakat sebagai upaya pencegahan penularan COVID-19 dengan melakukan sosialisasi edukasi. Salah satu kegiatan yang dilakukan MAFINDO kota Pontianak adalah edukasi kepada mahasiswa jurusan Sosiologi Fakultas Ilmu Sosial dan Ilmu Politik Universitas Tanjungpura Pontianak. Berikut statistik profil responden berdasarkan gender (jenis kelamin), program studi, semester dan usia responden.

Diagram 1 Jumlah Responden Berdasarkan Gender

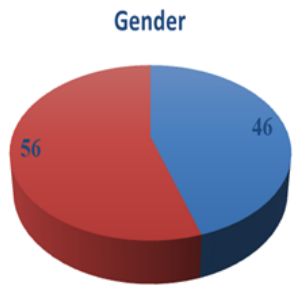

- Laki-laki $\backsim$ Perempuan

Sumber: Olahan peneliti

Berdasarkan diagram 1 menunjukkan keterwakilan gender baik laki-laki dan perempuan mempunyai kesempatan yang sama bahkan jumlah responden perempuan lebih banyak dari jumlah responden lakilaki. Responden laki-laki sebanyak 46 orang $(45,1 \%)$ dan Perempuan sebanyak 56 orang $(45,1 \%)$. MAFINDO memperhatikan keterwakilan gender karena semua gender berhak mengetahui informasi seputar COVID-19 dengan harapan keterwakilan

\section{Tabel 1}

\section{Literasi Kesehatan Berdasarkan Program Studi}

$* \mathrm{~S}=$ Sosiologi

*PS = Pembangunan Sosial

\begin{tabular}{|c|c|c|c|c|c|c|c|c|c|c|c|c|}
\hline & Questions & & Sanga & Setuju & & & & & & & & \\
\hline & & & $S$ & PS & $S$ & PS & $S$ & PS & $S$ & PS & $S$ & PS \\
\hline 1 & Saya mendapatkan & $\mathrm{N}$ & 17 & 6 & 50 & 22 & 2 & 3 & 1 & 0 & 1 & 0 \\
\hline & 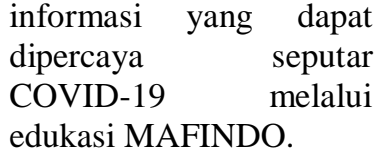 & $\%$ & 16.66 & 5.88 & 49.01 & 21.56 & 1.96 & 2.94 & 0.98 & 0 & 0.98 & 0 \\
\hline 2 & menjadi & $\mathrm{N}$ & 24 & 9 & 47 & 21 & 0 & 1 & 0 & 0 & 0 & 0 \\
\hline
\end{tabular}

mereka dapat membawa sikap positif untuk masyarakat sekitar mereka. Adapun rentang usia para responden antara usia 19-29 tahun, usia 19 tahun terdapat 11 orang $(10,8 \%)$, usia 20 tahun terdapat 32 orang $(31,4 \%)$, usia 21 tahun 28 orang $(27,5 \%)$, usia 22 tahun terdapat 18 orang $(17,6 \%)$, usia 23 tahun ada 5 orang $(4,9 \%)$, usia 24 tahun ada 5 orang (4,9\%), usia 25,27 dan 29 masingmasing terdapat 1 orang $(1,0 \%)$. Memperhatikan tabel tersebut bisa dilihat bahwa usia mayoritas dari responden adalah usia 20 tahun yaitu $31,4 \%$.

Selanjutnya berdasarkan tabel 1 menunjukkan bahwa peserta menerima dengan baik materi dari edukasi seperti yang terlihat pada tabel 1 nilai antara yang setuju, sangat setuju lebih dominan dari nilai untuk jawaban sangat tidak setuju, tidak setuju dan tidak tahu. Ini menujukkan bahwa edukasi dapat diterima dengan baik oleh peserta. Menarik jika melihat rentang hasil survey ini bahwa peserta menerima informasi edukasi dengan baik interval nilai antara 50\%-67\% dari total responden yang menggambarkan pencapaian dari semua peserta. Strategi yang digunakan dalam proses penyampaian edukasi juga menjadi salah satu faktor keberhasilan peserta dalam menyerap materi, metode yang digunakan adalah diskusi virtual dan menyampaikan materi secara daring di grup WhatsApp (WA) dengan menggunakan zoom meeting untuk mahasiswa yang mengampu mata kuliah Masyarakat Sipil dan Demokrasi, serta mahasiswa mata kuliah perbandingan pembangunan masyarakat 


\begin{tabular}{|c|c|c|c|c|c|c|c|c|c|c|c|c|}
\hline & $\begin{array}{l}\text { paham etika sampai } \\
\text { rumah sehabis bepergian. }\end{array}$ & $\%$ & 23.52 & 8.82 & 46.07 & 20.58 & 0 & 0.98 & 0 & 0 & 0 & 0 \\
\hline \multirow[t]{2}{*}{3} & \multirow{2}{*}{$\begin{array}{l}\text { Saya menjadi lebih } \\
\text { paham dan peduli kepada } \\
\text { kelompok disabilitas / } \\
\text { kelompok rentan yang } \\
\text { terdampak. }\end{array}$} & $\mathrm{N}$ & 24 & 7 & 46 & 22 & 1 & 2 & 0 & 0 & 0 & 0 \\
\hline & & $\%$ & 23.52 & 6.86 & 45.09 & 21.56 & 0.98 & 1.96 & 0 & 0 & 0 & 0 \\
\hline \multirow[t]{2}{*}{4} & \multirow{2}{*}{$\begin{array}{l}\text { Saya menjadi lebih } \\
\text { paham pola hidup bersih } \\
\text { dan sehat. }\end{array}$} & $\mathrm{N}$ & 34 & 15 & 36 & 16 & 0 & 0 & 1 & 0 & 0 & 0 \\
\hline & & $\%$ & 33.33 & 14.70 & 35.29 & 15.68 & 0 & 0 & 0.98 & 0 & 0 & 0 \\
\hline \multirow[t]{2}{*}{5} & \multirow{2}{*}{$\begin{array}{lr}\text { Saya tahu } & \text { tentang } \\
\text { gerakan "Ayo } & \text { Kawal } \\
\text { COVID-19" } & \text { dan } \\
\text { manfaatnya. } & \\
\end{array}$} & $\mathrm{N}$ & 22 & 7 & 45 & 22 & 4 & 2 & 0 & 0 & 0 & 0 \\
\hline & & $\%$ & 21.56 & 6.86 & 44.11 & 21.56 & 3.92 & 1.96 & 0 & 0 & 0 & 0 \\
\hline \multirow[t]{2}{*}{6} & \multirow{2}{*}{$\begin{array}{l}\text { Saya lebih memahami } \\
\text { cara identifikasi berita } \\
\text { hoax seputar isu COVID- } \\
19 .\end{array}$} & $\mathrm{N}$ & 23 & 6 & 43 & 22 & 4 & 3 & 0 & 0 & 1 & 0 \\
\hline & & $\%$ & 22.54 & 5.88 & 42.15 & 21.56 & 3.92 & 2.94 & 0 & 0 & 0.98 & 0 \\
\hline \multirow[t]{2}{*}{7} & \multirow{2}{*}{ 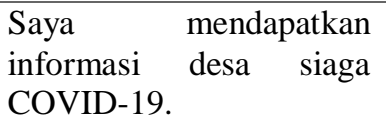 } & $\mathrm{N}$ & 17 & 6 & 46 & 18 & 8 & 7 & 0 & 0 & 0 & 0 \\
\hline & & $\%$ & 16.66 & 5.88 & 45.09 & 17.64 & 7.84 & 6.86 & 0 & 0 & 0 & 0 \\
\hline \multirow[t]{2}{*}{8} & \multirow{2}{*}{$\begin{array}{lr}\text { Saya } & \text { mendapatkan } \\
\text { kejelasan } & \text { informasi } \\
\text { tentang pembatasan sosial } \\
\text { berskala besar. }\end{array}$} & $\mathrm{N}$ & 21 & 6 & 44 & 24 & 5 & 1 & 0 & 0 & 1 & 0 \\
\hline & & $\%$ & 20.58 & 5.88 & 43.13 & 23.52 & 4.90 & 0.98 & 0 & 0 & 0.98 & 0 \\
\hline \multirow[t]{2}{*}{9} & \multirow{2}{*}{$\begin{array}{lcc}\text { Saya menjadi } & \text { lebih } \\
\text { paham tata } & \text { kelola } \\
\text { penanganan COVID- } 19 .\end{array}$} & $\mathrm{N}$ & 19 & 7 & 45 & 22 & 6 & 2 & 1 & 0 & 0 & 0 \\
\hline & & $\%$ & 18.62 & 6.86 & 44.11 & 21.56 & 5.88 & 1.96 & 0.98 & 0 & 0 & 0 \\
\hline \multirow[t]{2}{*}{10} & \multirow{2}{*}{$\begin{array}{l}\text { Saya menjadi lebih sadar } \\
\text { untuk menjaga kesehatan. }\end{array}$} & $\mathrm{N}$ & 38 & 16 & 33 & 15 & 0 & 0 & 0 & 0 & 0 & 0 \\
\hline & & $\%$ & 37.25 & 15.68 & 32.35 & 14.70 & 0 & 0 & 0 & 0 & 0 & 0 \\
\hline \multirow[t]{3}{*}{11} & \multirow{2}{*}{$\begin{array}{l}\text { Saya ingin terlibat } \\
\text { menjadi relawan COVID- } \\
19 \text { dengan melakukan } \\
\text { edukasi dan literasi } \\
\text { kesehatan. }\end{array}$} & $\mathrm{N}$ & 10 & 2 & 48 & 17 & 10 & 8 & 3 & 3 & 0 & 1 \\
\hline & & $\%$ & 9.80 & 1.96 & 47.05 & 16.66 & 9.80 & 7.84 & 2.94 & 2.94 & 0 & 0.98 \\
\hline & Jumlah & & 249 & 87 & 483 & 221 & 40 & 29 & 6 & 3 & 3 & 1 \\
\hline
\end{tabular}

Berdasarkan tabel 2 mempertegas temuan tentang pentingnya literasi kesehatan berdasarkan kelompok gender. Literasi kesehatan memainkan peranan penting dalam upaya mitigasi karena dapat membantu mengurangi dampak risiko pandemi. Selain itu, pengalaman langsung para individu dan masyarakat yang pernah atau rentan terpapar COVID-19 perlu dipertimbangkan sebagai bagian dari kepedulian dalam program mitigasi, terutama dalam upaya membangun ketangguhan komunitas dalam menghadapi
COVID-19. Masyarakat dengan literasi kesehatan yang rendah akan kewalahan dengan masalah kesehatan yang dihadapi karena keterampilan dan kemampuan mereka tidak mencukupi terkait dengan tuntutan dan kompleksitas yang diperlukan. Dengan kemungkinan buruk yang bisa terjadi terkait dengan literasi kesehatan, perlu kiranya diketahui tingkat literasi kesehatan masyarakat yang sesungguhnya agar dapat segera ditanggulangi berbagai kemungkinannya. 


\section{Literasi Kesehatan Berdasarkan Gender}

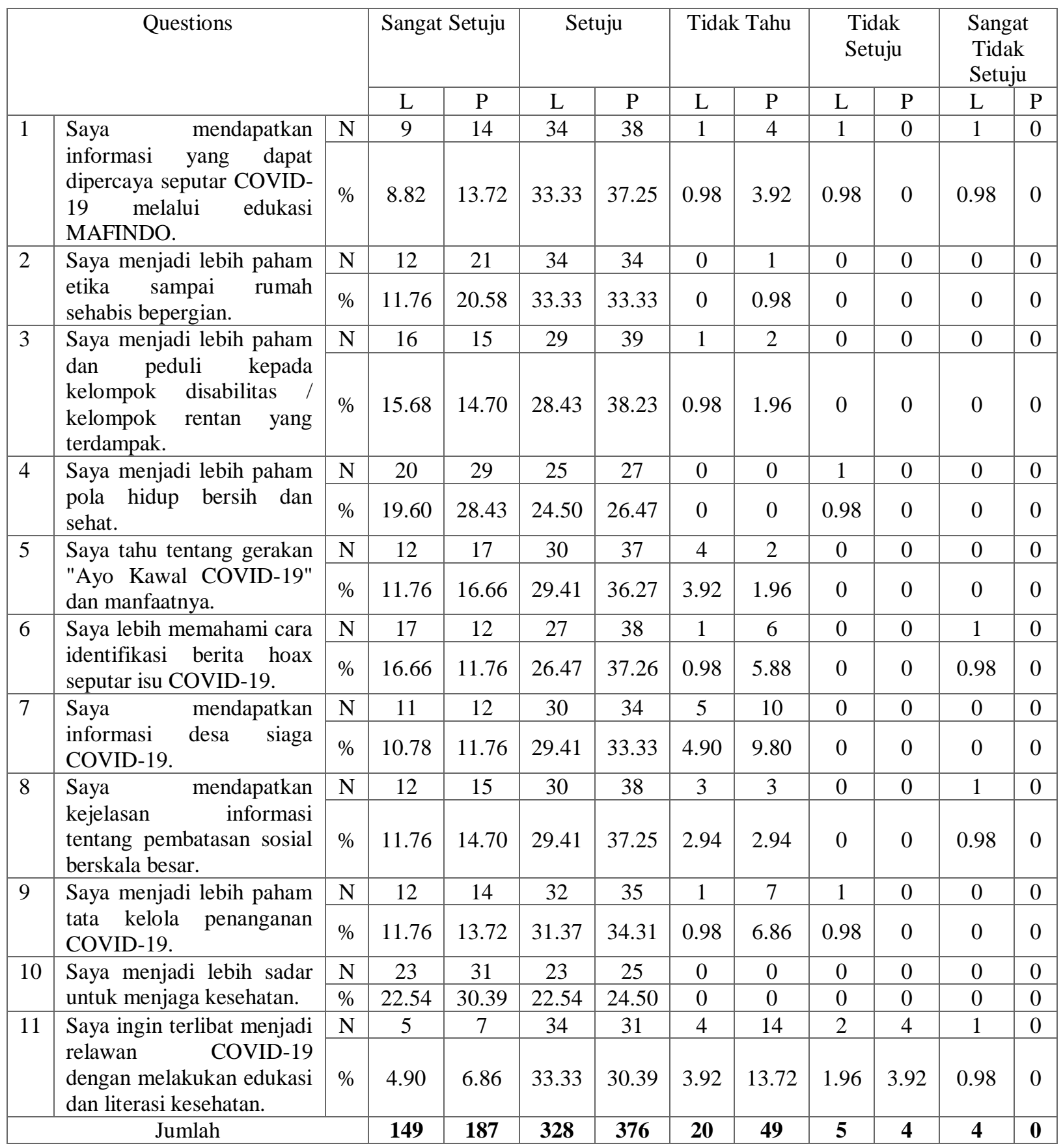

Berdasarkan tabel 1 dan 2 menjelaskan tidak terdapat korelasi antara perbedaan Gender dan Program studi dengan pemahaman mahasiswa mengenai literasi kesehatan. Penelitian ini sejalan dengan hasil dari penelitian-penelitian terdahulu yang juga menunjukkan bahwa perbedaan gender tidak memiliki hubungan yang signifikan terhadap tingkat literasi kesehatan seseorang (Nasriyanto, 2018; Santosa, 2012). Hasil penelitian juga menunjukkan bahwa tingkat literasi kesehatan secara signifikan dipengaruhi oleh faktor usia dan tingkat pendidikan. Pengaruh usia terhadap tingkat literasi kesehatan juga telah ditunjukkan oleh penelitian-penelitian sebelumnya dimana semakin lanjut usia seseorang maka semakin menurun pula tingkat literasi kesehatannya (Murray dkk, 2008; Shah dkk, 2010; Ozdemir dkk, 2010). Usia juga diyakini sebagai faktor yang mempengaruhi kemampuan kognitif seseorang, dimana 
ketika seseorang memasuki usia lanjut maka ia akan mengalami penurunan fungsi kognitif seperti mengalami kesulitan untuk memahami informasi kesehatan yang diberikan oleh tenaga kesehatan sehingga berdampak pada kemampuan literasi kesehatannya (NgEdward dan Omariba, 2010.

Hasil penelitian menunjukkan asosiasi positif antara tingkat pendidikan dengan tingkat literasi kesehatan ini sejalan dengan yang telah ditunjukkan oleh penelitian sebelumnya (Santosa, 2012; Nazmi dkk, 2015; Ozdemir dkk, 2010). Pendidikan dipercaya dapat mempengaruhi tingkat literasi kesehatan, baik secara langsung maupun tidak langsung.

Salah satu upaya untuk meningkatkan literasi kesehatan adalah pendidikan mitigasi pandemi untuk komunitas terutama kepada kelompok yang rentan terpapar daerah rawan bencana. Universitas memfasilitasi penelitian dan penilaian aspek bencana, ilmiah, metodologis, sosial-budaya, dan ekonomi, termasuk teknik, kearifan lokal, pendidikan bencana, dan sosialisasi. Kapucu dan Khosa (2013) menambahkan bahwa peran universitas di masyarakat termasuk pelaksanaan berbagai penelitian dan pembentukan jaringan kemitraan dengan masyarakat sekitar. Hasil penelitian ini sejalan dengan temuan sebelumnya Chung dan Yen (2016)] bahwa keterampilan pencegahan bencana di antara para

\section{Limitations}

Dataset ini memiliki beberapa batasan yang harus diperhatikan. Data ini dikumpulkan dengan pendekatan purposive sampling. Para responden adalah mahasiswa yang mendapatkan materi Edukasi Hidup Sehat yang disusun MAFINDO. Kami dapat melakukan justifikasi hubungan sebab akibat pasca edukasi terhadap tingkat literasi kesehatan dan perubahan perilaku responden terhadap gerakan literasi edukasi. Dalam studi ini informan ditanyai tentang eksposur mereka terhadap kebijakan pemerintah dalam menangani COVID-19 yaitu melalui program PPSB dan desa siaga/tanggap administrator sekolah dan guru di Taiwan relatif baik.

Di antara empat jenis pengetahuan, ditemukan bahwa mahasiswa FISIP UNTAN memiliki tingkat pemahaman yang baik terkait dampak pandemic COVID-19. Bergelut langsung dengan dampak pandemi telah menumbuhkan sosial-emosional dan kesadaran kolektif untuk melakukan edukasi tentang pentingnya memilah informasi seputar COVID-19 dan tata kelola hidup aman dan sehat semasa pandemic. Selain itu, mereka yang mendapatkan materi edukasi anti hoax pemberitaan COVID-19 dan memiliki kemampuan identifikasi dan cek fakta berita hoax memiliki tingkat perilaku yang baik untuk menjadi relawan edukasi dan literasi anti hoax di komunitas mereka. Di masa Pandemi ini kemampuan identifikasi dan cek fakta informasi hoax menjadi pengetahuan penting agar mereka dapat menjadi fasilitator dan motivator program desa Siaga COVID-19. Dengan kemampuan cek fakta ini mahasiswa mampu membangun kesiapsiagaan dan meningkatkan kesadaran dan pengetahuan public dalam menghadapi pandemic COVID-19. Namun, para mahasiwa belum terlalu memahami faktor-faktor potensial dan krusial dalam mewujudkan Desa Siaga COVID-19 karena keterlibatan mereka dalam program ini belum terlalu banyak dilibatkan dan disosialisasikan seperti yang dijelaskan pada tabel 2.

COVID 19. Penelitian di masa depan dapat mengeksplorasi lebih mendalam dengan pendekatan kualitatif atau mix metode tentang analisa dampak penerapan kebijakan PPSB dan desa siaga COVID-19 terhadap tingkat ketangguhan masyarakat baik yang berada di di perdesaan dan perkotaan. Faktor demografis, status sosial ekonomi, tingkat pendidikan, usia dan gender menjadi indikator yang bisa dibandingkan. Diharapkan bahwa penelitian ini akan mendorong penelitian masa depan di bidang ini yang akan mengeksplorasi faktor-faktor ini secara lebih mendalam. 


\section{KESIMPULAN}

Literasi kesehatan didefinisikan sebagai atribut yang melekat dari kemampuan literasi masyarakat yang juga dipahami sebagai keadaan dinamis masyarakat yang dipengaruhi oleh factor di luar dirinya, seperti petugas kesehatan, institusi kesehatan dan pemerintah sebagai pembuat kebijakan serta budaya yang melingkupi masyarakat. Literasi kesehatan dapat berperan besar dalam menentukan keberhasilan pembangunan kesehatan di Indonesia jika diketahui pemetaannya sehingga memudahkan pemerintah dalam mencapai masyarakat sehat, mandiri dan berkeadilan. Sebagai simpulan mahasiswa Fakultas Ilmu Sosial dan Politik Universitas Tanjungpura memiliki tingkat literasi kesehatan yang baik yang ditandai dengan adanya pemahaman dalam sikap dan keterampilan memilah sumber informasi yang benar tentang panduan hidup sehat dan aman semasa pandemic COVID-19 di Kalimantan Barat. Temuan menarik di sini adalah bahwa faktor gender tidak mempengaruhi tingkat literasi kesehatan sebagaimana sebagian besar penelitian menemukan bahwa gender memiliki peran yang signifikan untuk membedakan kemampuan literasi antara perempuan dan laki-laki.

Temuan ini menjadi pengetahuan khusus untuk literasi edukasi kesehatan semasa pandemic yang perlu diselidiki lebih lanjut sehubungan dengan keberagaman latar belakang budaya dan etnis di Kalimantan Barat. Diperlukan penelitian yang lebih mendalam untuk menemukan faktor sosial budaya dan psikologis terkait tingkat kesadaran kolektif masyarakat dalam mendukung gerakan literasi edukasi kesehatan terutama sekali dengan menggunakan analisa gender yang menyediakan data terpilah dari aspek partisipasi, akses, kontrol dan manfaat. Temuan menarik lainnya adalah bahwa pilihan untuk mendukung gerakan literasi edukasi kesehatan semasa pandemic menunjukkan bahwa responden memiliki kesadaran tinggi dalam gerakan sosial dan tingkat empati kemanusiaan. Tingginya tingkat kesadaran kolektif memberikan pengaruh kepada tingkat partisipasi dan kemanfaatan edukasi literasi kesehatan semasa pandemic. Temuan ini menyiratkan bahwa para responden atau anak-anak muda ini memiliki potensi untuk terlibat dalam program kesiapsiagaan atau mitigasi pandemic di desa mereka yang dikenal dengan program Desa Tanggap COVID-19. Oleh karena itu, program edukasi literasi kesehatan dengan materi cara mengidentifikasi atau memilah informasi kesehatan dan pandemic, tata kelola hidup sehat dan aman semasa pandemi COVID-19 harus diintegrasikan ke dalam proses pembelajaran di kampus dan di sekolah. Untuk temuan di atas, kami merekomendasikan perlunya upaya rekonstruksi kurikulum berbasis soft skill untuk meningkatkan literasi kesehatan dan literasi media dalam program pendidikan di lembaga pendidikan tinggi.

\section{DAFTAR PUSTAKA}

Barrett S.E. \& Puryear J.S. (2006). Health

Literacy: Improving Quality of Care in Primary Care Settings. J. Health Care Poor Underserved, 17 (-): 690-697.

Berkman, N. D., Davis, T.C.\&McCormack,

L. (2010). Health Literacy: What Is It? Journal of Health Communication, $15(-)$ : 9-19.

Berry, Dianne (2007) Health Communication Theory and Practice, Open University Press, Mc Graw Hill Education, England

Chung, S., And Yen, C. (2016). Disaster Prevention Literacy Among School Administrators And Teachers; A Study On The Plan For Disaster Prevention And Campus Network Deployment And Experiment In Taiwan. Journal of Life Science, 10(2016), 203-214. 
Devlin, M., Kristensen, S., Krzaklewska, E., \&Nico, M. (2017). Learning Mobility Social Inclusion And NonFormal Education: Access, Processes, And Outcomes (Vol. 22). Council Of Europe

Djalante, R., Lassa, J., Setiamarga, D., Sudjatma, A., Indrawan, M., Haryanto, B.,Warsilah, H. (2020). Review and analysis of current responses to COVID-19 in Indonesia: Period of January to March 2020. Progress in Disaster Science, $\quad 6, \quad 100091$. https://doi.org/https://doi.org/10.101 6/j.pdisas.2020.100091

Fadilah.Muhyiatul., Permanasari.Anna.,

Riandi., Mary, Enok. (2020). The Level Of Disaster Literacy Of EarthquakeExperienced Students In Mathematics And Science Faculty Of State University In Indonesia. Journal Of Engineering Science And Technology Special Issue On AASEC 2019, February (2020) 30 38 (C) School Of Engineering, Taylor's University.

Fitriyah (2017). Literasi Kesehatan pada Penderita Penyakit Kronis TB Paru di Kabupaten Sumenep. (Skripsi). Repositori Universitas Airlangga.

Freedman, D. A., Bess, K. D., Tucker, H. A., Boyd,D. L., Tuchman, A. M.\& Wallston, K. A. (2009).

Public Health Literacy Defined. American Journal of Preventive Medicine, 36 (5): 446-451.

Gostic, K., Gomez, A. C., Mummah, R. O.,

Kucharski, A. J., \& Lloyd-Smith, J. O. (2020).The estimated effectiveness of symptom and risk screening to prevent the spread of COVID-19. ELife, $\quad 9(\mathrm{e} 55570), \quad 1-18$ https://doi.org/10.7554/eLife.55570
Jang, K., \& Baek, Y. M. (2019). When

Information From Public Health Officials Is Untrustworthy: The Use Of Online News, Interpersonal Networks, And Social Media During The Mers Outbreak In South Korea. Health Communication. Https://Doi.Org/10.1080/10410236.2 $\underline{018.1449552}$

Kapucu, N.; and Khosa, S. (2013). Disaster

resiliency and culture of preparedness for university and college campuses. Administration \& Society, 45(1), 337.

Mok, O. N. A. (2011). Non-Formal Learning: Clarification Of The Concept And Its Application

In Music Learning. Australian Journal Of Music Education, 1, 11-15

Murray, T.S., Hagey, J., Willms, D., Shillington, R., dan Desjardins, R. (2008) Health literacy in Canada: a healthy understanding. Ottawa, CA: Canadian Council on Learning

Nasriyanto, E. N. (2018). Pengaruh Determinan Sosial Terhadap Tingkat Literasi Kesehatan

Pada Mahasiswa Universitas Indonesia di Kota Depok. (Tesis). Repositori Universitas Indonesia.

Nazmi, N., Rudolfo, G., Restila, R. Emytri, E.(2015). Faktor-faktor yang mempengaruhi literasi

kesehatan di fasilitas pelayanan kesehatan: systematic review. Prosiding seminar Nasional Penelitian dan Pengabdian Masyarakat, Universitas Islam Bandung

Ng, Edward., Walter, D., \& Omariba, R. (2010). Health Literacy and immigrants in Canada: 
Determinants and effects on health outcomes. Ottawa. Retrieved from https://pdfs.semanticscholar.org/7f7d 178e6f2f0e183a02adee41ce1989a3fc 2c714.pd

Norqvist, L., Lefûer, E., \& Jahnke, I. (2016).Sweden And Informal Learning-Towards Integrated Views Of Learning In Digital Media World: A Pedagogical Attitude? Inm.

Ozdemir, H., Alper, Z., Uncu, Y., \& Bilgel, N. (2010). Health literacy among adults: a study from Turkey. Health Education Research, 25(3), 464-477.

\section{http://doi.org/10.1093/her/cyp068}

Parmer, J., Baur, C., Eroglu, D., Lubell, K., Prue, C., Reynolds, B., \& Weaver, J. (2016). Crisis And Emergency Risk Messaging In Mass Media News Stories: Is The Public Getting The Information They Need To Protect Their Health? Health Communication.

Https://Doi.Org/10.1080/10410236.2 $\underline{015.1049728}$

Rahmaniah, S., \& Rupita, H. (2020). Stop Hoax Indonesia: Digital Literacy and Education to Prevent Hoax and Hate Speech in the Regional Head Election of West Kalimantan 2020.
Talent and Development and Excellence, 12(2s), 1266-1274.

Santosa, K.M. (2012). Faktor-faktor yang berhubungan dengan tingkat kemelekan kesehatan pasien di klinik dokter keluarga Fakultas Kedokteran Universitas Indonesia Kiara DKI Jakarta.(Tesis). Repositori Universitas Indonesia

Shah, L. C., West, P., Bremmeyr, K., \& Savoy-Moore, R. T. (2010). Health literacy instrument in family medicine: the newest vital sign ease of use and correlates. Journal of the American Board of Family Medicine, 23(2), 195-203. http://doi.org/10.3122/jabfm.2010.02 .070278

UNESCO.World Health Organization (WHO). (2013). Health Literacy: The Solid Facts. Denmark: WHO Regional Office for Europe Weiss, B.D. (2007) Health Literacy and Patient's Safety: Help patients Understand manual for Clinicians 2ndedition. Chicago: American Medical Association Foundation

Zarcadoolas.C, Pleasant.A.F, Greer. D.S (2006), Advancing Health Literacy, A framework for Understanding and Action, JohnWiley \& Sons, Inc, CA 
Bidang Ilmu Pengetahuan Sosial 